\title{
Efficiency of phosphorus use in potato clones in two contrasting growing seasons
}

\author{
Darlene Sausen ${ }^{1 *}$, Ivan Ricardo Carvalho ${ }^{2}$, Miriam da Silva Tavares ${ }^{3}$, Márcio Renan Weber Schorr ${ }^{4}$, Ritieli \\ Baptista Mambrin ${ }^{5}$, Jover da Silva Alves ${ }^{1}$, Camila Peligrinotti Tarouco ${ }^{1}$, Alessandro Dal ${ }^{~}$ Col Lucio $^{1}$, Francine \\ Lautenchleger $^{6}$, Fernando Teixeira Nicoloso ${ }^{1}$
}

${ }^{1}$ Federal University of Santa Maria, Santa Maria, RS, Brazil

${ }^{2}$ Northwest Regional University of the State of Rio Grande Do Sul, ljuí, RS, Brazil

${ }^{3}$ Goiás State University, Posse, GO, Brazil

${ }^{4}$ National Supply Company, Porto Alegre, RS, Brazil

${ }^{5}$ Riograndense Higher Education Center, Marau, RS, Brazil

${ }^{6}$ University of the Midwest, Guarapuava, PR, Brazil

\section{*Corresponding author: darlene_sn@yahoo.com.br}

\begin{abstract}
In Rio Grande do Sul the potato (Solanum tuberosum L.) can be grown in fall and spring. However, due to the contrasting weather conditions between these two seasons, which directly influence the growth of plants and the formation of tubers, it is necessary to identify potato clones adapted to such growing conditions. Thus, this work was carried out to characterize the efficiency of $P$ use in potato clones grown in two contrasting seasons, in an off-soil growing system using sand as a substrate. The treatments were combined in a $2 \times 4 \times 2$ factorial, consisting of two levels of $P$ in the nutrient solution ( 2.32 and $\left.23.2 \mathrm{mg} \mathrm{P} \mathrm{L}^{-1}\right)$, four potato clones (Asterix, Atlantic, SMIC 148-A and SMINIA 793101-3) and two growing seasons (spring and fall). The number of leaves and tubers per plant, the fresh and dry mass of the tubers, fresh mass of the shoot, P concentration in shoot and tubers, and efficiency of $P$ use were determined. There is a difference between the potato clones in terms of the efficiency of $P$ use in the spring and autumn crops of Rio Grande do Sul. Asterix and SMINIA 793101-3 clones show higher productivity in the spring growing and without P. restriction. SMIC 148-A clone was not influenced by the growing season, as long as the availability of $P$ is not a limiting factor. Atlantic clone shows good production when grown in the fall, regardless of the level of $P$ used.
\end{abstract}

\section{Introduction}

Rio Grande do Sul (RS) is responsible for only $12 \%$ of the national potato production (Solanum tuberosum L.) while the main producing states in this harvest are Minas Gerais (32\%) and Paraná (23\%) (IBGE, 2017). This small participation of the state in potato production occurs due to the lack of cultivars adapted to environmental conditions, as well as to the requirements of the industry (Pereira, 2003). Most potato cultivars made available to farmers in RS are not adapted to subtropical regions, where two annual crops are possible (Souza et al., 2011).

Potatoes in RS can be grown in the spring (AugustDecember), where the plants thrive under increasing conditions of photoperiod, temperature and availability of solar radiation, and in the fall (February-June) under decreasing conditions of these meteorological factors. However, these environmental variations directly influence the growth of plants and the formation of potato tubers (Beukema and Zaag, 1990). In addition, the availability of nutrients affects the growth and development of vegetables (Lynch, 2011; Vance et al., 2003) and also the quantity and quality of the final product, especially for less adapted cultivars (Fernandes et al., 2016; Gnocato et al., 2014).

In order to obtain pre-basic potato seeds (mini-tubers) with high physiological quality, off-soil growing systems have been used (Bisognin and Dellai, 2015), which have the advantage of high health, tuber productivity and even provide greater control of the nutrients used. Because phosphorus $(P)$ is a nutrient with finite mineral reserves for the production of fertilizers, its rational use has also become a relevant concern in potato production. The identification of efficient clones in the use of $\mathrm{P}$ with productive potential in the two annual crops, which occurs in the subtropical regions, has been a challenge for potato breeding.

Assuming that the availability of $P$ in the substrate interferes with the efficiency of use of $P$ by plants, the present work hypothesizes that contrasting times of growing influence the efficiency of use of $P$ in potato clones. Such a response could assist in the implementation of a more appropriate management of the use of phosphate fertilizers for the production of seed potatoes. Thus, the objective of this work was to determine the efficiency of use of $P$ in potato clones grown in two contrasting seasons, in an off-soil growing system, using sand as a substrate.

\section{Results and discussion}

The Atlantic, SMIC 148-A and SMINIA 793101-3 clones showed a higher number of leaves per plant when grown in the spring and in the presence of a high level of $P$. The Asterix clone also had a higher number of leaves in the 
spring, but the variation of $P$ availability did not influence this parameter (Table 1). Plants with a greater number of leaves can more quickly reach the leaf area index that provides the maximum biomass production (Bisognin and Dellai, 2015). Possibly, due to this and the greater solar radiation in the spring growing, this is the preferred time for the production of tubers in RS. In the fall, the highlight was the Atlantic clone, more adapted to the temperate climate, which had a higher number of leaves among the clones at both low and high P levels, respectively with 22.3 and 18.6 leaves per plant.

As for the number of tubers per plant, between seasons it was found that the clones produced a greater number of tubers in decreasing condition of photoperiod, temperature and availability of solar radiation (Table 1); these conditions naturally promote a reduction in the crop development cycle, leading the plants to tuberize earlier. When analyzing each growing season in isolation, we found that in the spring the highest production of tubers occurred under a high level of $P$ and in the fall, under a low level of $P$ (Table 1); intensifying the hypothesis that the development of a plant will be limited by that missing nutrient, making the plant, even in limited $P$ conditions, anticipate the reproductive phase and allocate all its reserves for the production of tubers (seeds).

The use of a nutrient solution containing a higher level of $P$ also provided greater production of fresh tuber mass in the spring growing, being $113,73,68$ and $163 \%$ higher than at the low level of $P$, respectively for the Asterix, Atlantic, SMIC 148-A and SMINIA 793101-3 clones (Table 1). These results confirmed that the presence of $P$ is essential for tuber production, and $\mathrm{P}$ acts by stimulating the formation of larger tubers (Fernandes et al., 2015; Prezotti et al., 1986). In the fall, $P$ effectively increased the tuber fresh mass only for clone SMIC 148-A (31.6\%).

In the production of mini-tubers in a closed growing system without the use of soil, the harvest is carried out at the very beginning of the growth phase of the tubers, where the effect of environmental conditions on the partition of the photoassimilates is less than at the end of the cycle, different from what happens in commercial potato production crops for consumption. In this way, the number of tubers becomes more important than the fresh mass, since the mass can be managed for the duration of the crop cycle until the moment of harvest (Muller et al., 2007), which indicates that it is possible to obtain satisfactory production of tubers also in fall growing as long as the $P$ level is managed as shown in this study (Table 1 ). Contrasting results between growing seasons in terms of the number and tuber fresh mass per plant were also found by Muller et al. (2007), which, similar to that found in this work in fall growing, observed a reduction in the tuber fresh mass and an increase in their number with a reduction in the concentration of nutrients in the nutrient solution, while in the spring the number and tuber fresh mass increase as the concentration of nutrients in the solution increases.

The Asterix and SMINIA 793101-3 clones showed the highest production of tuber fresh mass, respectively 74.6 and 101.9 g plant ${ }^{-1}$, when grown with high availability of $P$ associated with spring growing (Table 1 ). In this growing season, when the temperature and photoperiod are increasing, there was a stimulus to the growth and development of the plants of these clones, with a consequent increase in the production of tubers. On the other hand, the Atlantic clone showed better productive performance in fall growing, despite showing little responsiveness to the increase of $P$ in the nutrient solution for the production of tubers (70.1 and $76 \mathrm{~g}$ plant $^{-1}$ in the low and high levels, respectively). For the SMIC 148-A clone, the highest production of tuber fresh mass was achieved at the high level of $P$ regardless of the growing season (78 and 80 g plant $^{-1}$ in spring and fall, respectively); this indicates that the SMIC 148-A clone was not influenced by the growing season regarding the production of tuber fresh mass, as long as the availability of $P$ is not a limiting factor.

Regarding the tuber dry mass content, in relation to fresh mass, the Asterix clone, under high level of $P$, and the Atlantic, under low level of $P$, in spring growing presented, respectively, 20 and $23 \%$ (Table 1 ) which is desirable in potato clones destined for frying because it provides good industrial performance (Muller et al., 2009). Therefore, for the Atlantic clone, the preferred growing season to achieve an adequate tuber dry mass content can be managed with the $P$ restriction, since the Atlantic clone, which is adapted to temperate weather and therefore more productive in fall, presented dry mass content closer to the ideal in the spring under low level of P. The same occurred for the SMIC 148-A clone, which in the spring under low level of $\mathrm{P}$ presented $19.7 \%$ of tuber dry mass content, close to the most suitable range between 20 and 24\% (Oliveira et al., 2006). SMINIA 793101-3 showed dry mass content above $24 \%$, in spring growing under high P level and below $16 \%$, when grown in the other conditions tested in this study, remaining outside the ideal range for processing in the form of chips, which has also been reported by other authors for this clone (Bisognin et al. 2008), being firmer in cooking and, therefore, indicated for the preparation of roasted dishes.

In the spring crop there was a reduction in the shoot dry mass for all clones due to the reduction of the level of $P$ in the nutrient solution (Table 2). According to Mendes et al. (2011), for nutritional stress to be significant, a reduction in productive potential of at least $40 \%$ should be observed, considering the stress-free environment as a reference, which occurred in this work effectively for all clones in the spring. However, in fall growing, the variation in the availability of $P$ in the nutrient solution resulted in a less significant reduction, which indicates that the growing season influenced the responses to $\mathrm{P}$ in the growth of potato clones. All clones showed higher production of shoot dry mass under a high level of $P$, with Asterix, SMIC 148-A and SMINIA 793101-3 in spring, while Atlantic in fall (Table 2). Regardless of the preferred growing season for each clone, the concentration of $P$ in the shoot and in the tubers was higher at the high level of $\mathrm{P}$ in the fall growing for all tested clones (Table 2). This shows that the sensitivity of each clone to the photoperiod does not interfere with the $\mathrm{P}$ absorption capacity of the nutrient solution, but rather the allocation of $P$. As a result, the efficiency of $P$ use was higher in the spring, regardless of the level of $P$, for the four clones tested (Table 2). The Asterix and SMINIA 793101-3 clones used $P$ better under a high level of nutrient in the nutrient solution, while Atlantic and SMIC 148-A made equal use of $P$ among the $P$ levels tested at this time. Several studies have shown that the more $\mathrm{P}$ available to plants, the lower the efficiency of use (Gondim et al., 2010; Moura et al., 2001). In the fall, as a result of the plants concentrated more $P$ when grown at this time, less use of $P$ was expected at that time, with the SMINIA 793101-3 clone under high level and SMIC 148 clone under low level, those that best used $\mathrm{P}$ in total dry mass 
Table 1. Effect of $P$ levels in the nutrient solution on the number of leaves, the number of tubers, the tuber fresh mass and the tuber dry mass content of the Asterix, Atlantic, SMIC 148-A, SMINIA 793101-3 clones; evaluated at 62 days after planting in a closed growing system with sand as a substrate, in the spring and fall of Rio Grande do Sul. Santa Maria, RS, 2018.

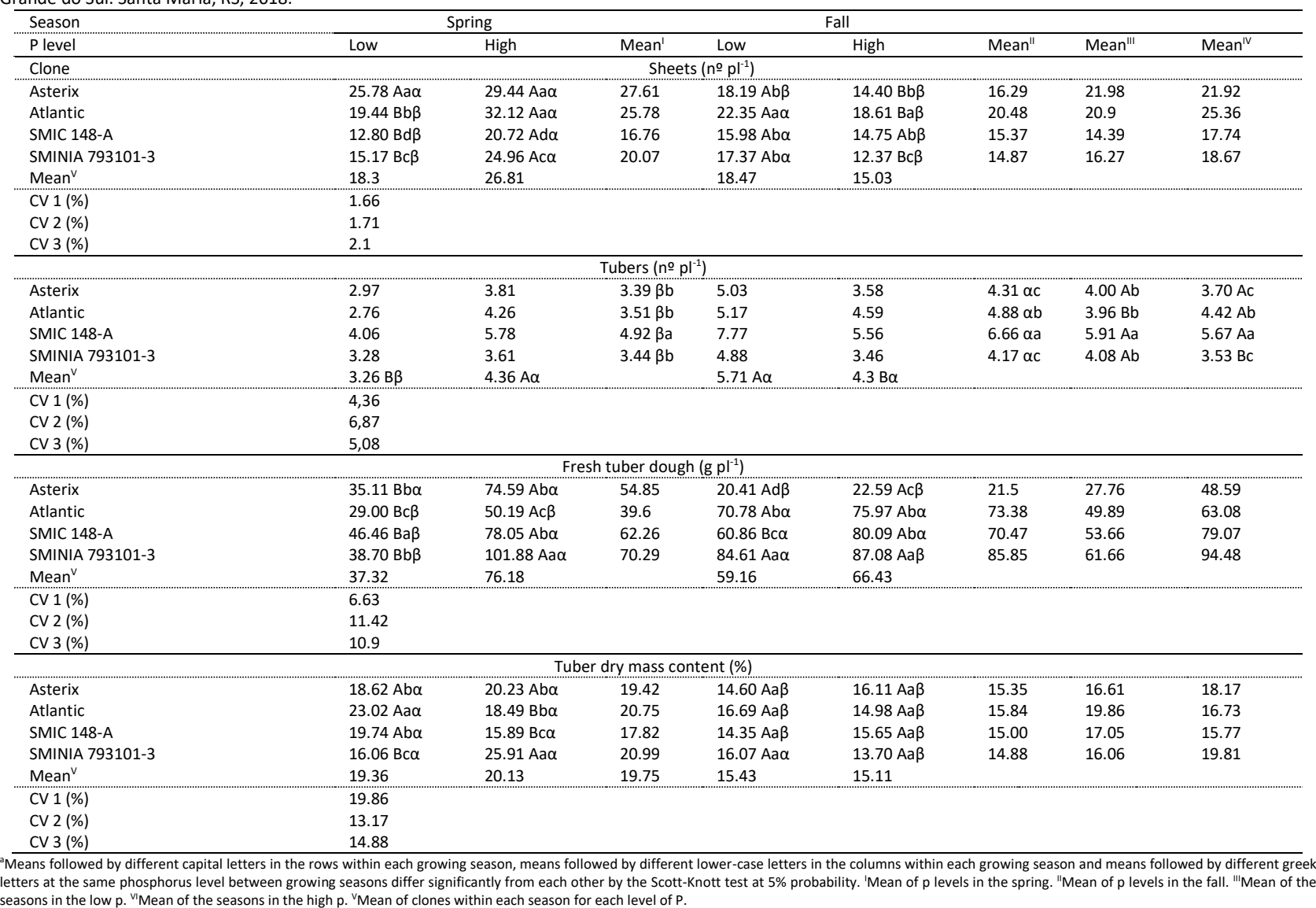

Table 2. Effect of $P$ levels in the nutrient solution on the shoot dry mass, on the concentration of $p$ in the shoot and tubers and on the $P$ use efficiency in the whole plant of the Asterix, Atlantic, SMIC 148-A, SMINIA 793101-3 clones; evaluated at 62 days after planting in a closed growing system with sand as a substrate, in the spring and fall of Rio Grande do Sul. Santa Maria, RS, 2018.

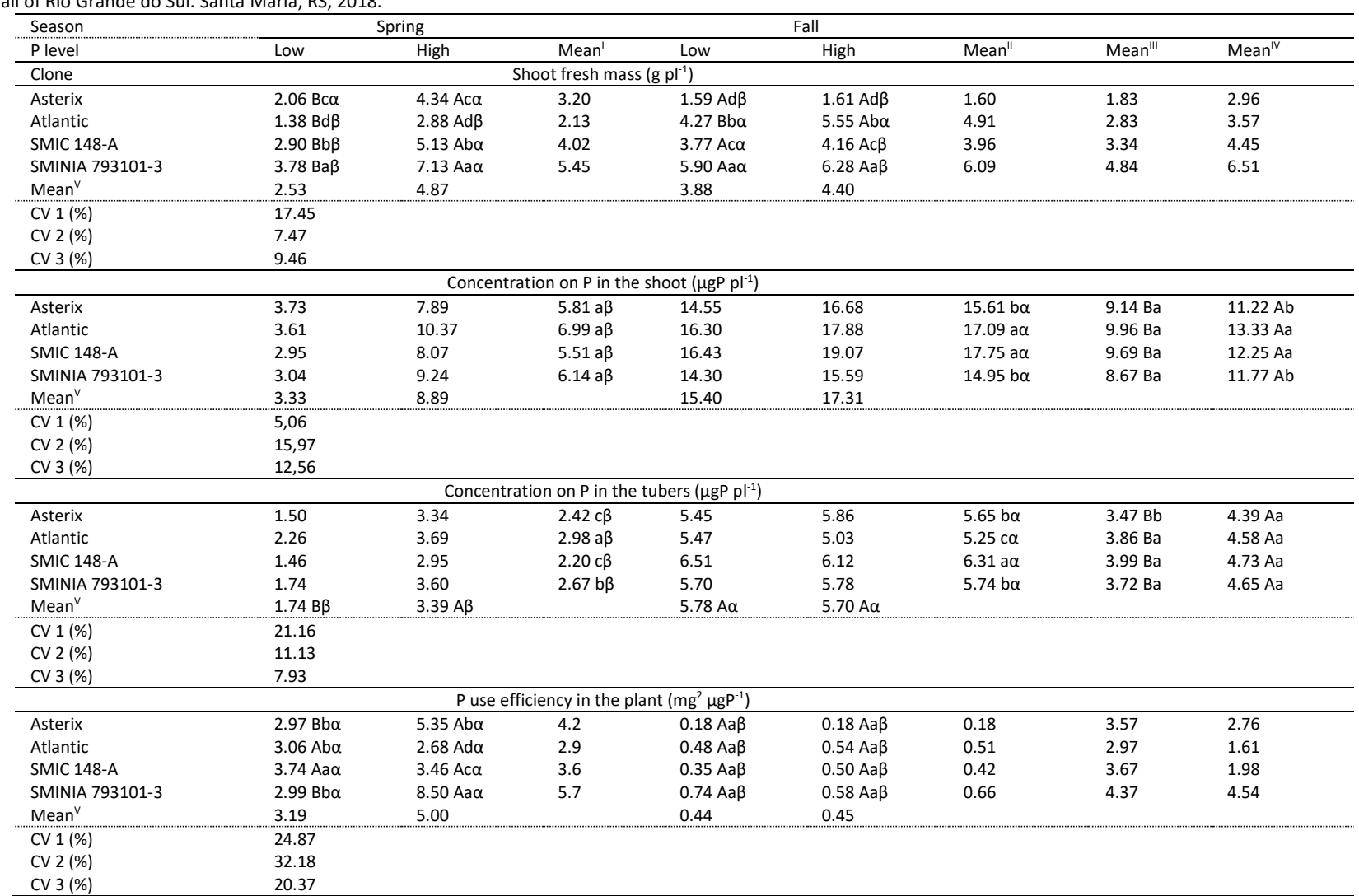

aMeans followed by different capital letters in the rows within each growing season, means followed by different lower-case letters in the columns within each growing season and means followed by different Greek letters at the same phosphorus level between growing seasons differ significantly from each other by the Scott-Knott test at $5 \%$ probability. Mean' of P levels in the spring. Mean " of P levels in the fall. Mean'" of the seasons in the low P. Mean" of the seasons in the high P. Mean" of clones within each season for each level of P. 
production, producing 8.5 and $3.7 \mathrm{mg}^{2} \mu \mathrm{g} \mathrm{P}$ respectively (Table 2).

\section{Materials and methods}

The experiment was carried out in a greenhouse located in Santa Maria - RS (29o 42 '56"S, 53 43' 13"W and 95m altitude), during the spring crops (07/30 - 11/14/2013) and fall (03/10 - 06/16/2014). The clones SMIC 148-A, SMINIA 793101-3 and the cultivars Asterix and Atlantic were evaluated and, for simplification purposes, they will be referred to simply as clones.

Asterix has a semi-late cycle and is widely used industrially in the manufacture of pre-fried frozen French fries. Atlantic, on the other hand, has a medium-early cycle and is indicated for the production of chips. The SMINIA 793101-3 and SMIC 148-A clones are part of the Potato Genetics and Breeding Program at the Federal University of Santa Maria and have the potential to be incorporated into the production system (Souza et al., 2014; Zanon et al., 2013), with the SMINIA 793101-3 clone being the most adapted to the subtropical climate region of Brazil.

The experiment was carried out in a randomized block design in sub-divided plots using six replications and the treatments were combined in a factorial with two growing seasons in the main plot (spring and fall), two levels of $P$ in the subplot ( 2.32 and $23.2 \mathrm{mgP} \mathrm{L}^{-1}$ ) and four potato clones in the sub-plot (Asterix, Atlantic, SMIC 148-A and SMINIA 793101-3). The experimental unit was composed of three plants.

The plant material was previously micropropagated and, later, acclimatized for 27 and 21 days in spring and fall, respectively, in a growing system without the use of soil. After that period, the uniform plants (with approximately 10 $\mathrm{cm}$ long and six leaves larger than $1 \mathrm{~cm}$ ) were transplanted to a sand growing system (Bandinelli et al., 2013), at a spacing of 10 by $10 \mathrm{~cm}$. The sand used for this experiment was washed once with sodium hypochlorite and three times with tap water. Three irrigations of nutrient solution were carried out during the day, so that the entire substrate was saturated with solution, with the aid of a digital programmer and a low flow pump for a set of four trays. The excess solution was drained through an orifice located at the base of the tray and conducted through a system channeled to a reservoir.

The $\mathrm{P}$ treatments consisted of 5 and $50 \%$ of the standard $P$ concentration of the nutrient solution for the growing of potato without soil described by Bisognin et al. (2016), called low $\left(2.32 \mathrm{mgP} \mathrm{L}^{-1}\right)$ and high $\left(23.2 \mathrm{mgP} \mathrm{L}^{-1}\right)$ levels of $\mathrm{P}$. These levels of $\mathrm{P}$ were previously tested by the authors and give plants restricted $\left(2.32 \mathrm{mgP} \mathrm{L}^{-1}\right)$ and normal growth $(23.2 \mathrm{mgP}$ $\mathrm{L}^{-1}$ ). The nutrient solution had the following composition (in $\mathrm{g} \mathrm{L}^{-1}$ ): $0.50 \mathrm{KNO}_{3}, 0.724 \mathrm{Ca}\left(\mathrm{NO}_{3}\right)_{2}, 0.01$ and $0.102 \mathrm{KH}_{2} \mathrm{PO}_{4}$ (at low and high level), 0.106 and $0.0559 \mathrm{KCl}$ (at low and high level), $0.308 \mathrm{MgSO}_{4} \cdot 7 \mathrm{H}_{2} \mathrm{O}$ and $0.1 \mathrm{ml}$ of micronutrient solution. For the preparation of $1 \mathrm{~L}$ of micronutrient solution, (in g L-1): $0.7 \mathrm{Na}_{2} \mathrm{MoO}_{4}, 15 \mathrm{H}_{3} \mathrm{BO}_{3}, 2.5 \mathrm{CuSO}_{4}, 20$ $\mathrm{MnSO}_{4}$ and $10 \mathrm{ZnSO}_{4}$ were used. The electrical conductivity (EC) was maintained at $2 \mathrm{dS} \mathrm{m}^{-1}$ (water was used to reduce the $\mathrm{EC}$ when necessary) with the $\mathrm{pH}$ maintained at 5.5 being adjusted every two days.

The plants were harvested before the senescence period started, still during the tuberization period, without the tubers having reached $90 \%$ of the final size, still at T90 according to the phenological scale of the potato plant described by Heldwein et al. (2009), approximately 62 days after planting. After collection, the plants were washed in tap water and divided into aerial parts, tubers and roots. The dry mass was determined after drying the material for 15 days in an oven at $60{ }^{\circ} \mathrm{C}$. The effects of $\mathrm{P}$ levels in the nutrient solution in the two growing seasons for each clone were evaluated for each plant according to the average number of leaves, the average number of tubers, the fresh mass of tubers (in grams), the dry masses of shoot and tuber (in grams).

To determine the $\mathrm{P}$ content, samples of the dry matter of shoots, roots and tubers were weighed and macerated. The analysis of total $P$ in the tissue was performed according to Tedesco et al. (1995), with the digestion of $0.2 \mathrm{~g}$ of tissue with $0.7 \mathrm{~g}$ of digestion mixture $\left(100 \mathrm{~g}\right.$ of $\mathrm{Na}_{2} \mathrm{SO}_{4}, 10 \mathrm{~g}$ of $\mathrm{CuSO}_{4} .5 \mathrm{H}_{2} \mathrm{O}$ and $1 \mathrm{~g}$ of selenium) in sulfuric acid $\left(\mathrm{H}_{2} \mathrm{SO}_{4}\right)$ with hydrogen peroxide $\left(\mathrm{H}_{2} \mathrm{O}_{2}\right)$ remaining in the digestion block for one hour at $350^{\circ} \mathrm{C}$. The determination of $\mathrm{P}$ in plant tissue extracts was performed by colorimetry, according to Murphy and Riley (1962). The accumulation of $P$ in the entire plant was obtained by the product between the $P$ content and the total dry mass. Once these data were obtained, the $P$ utilization efficiency index (PUE) was estimated: (total dry mass of the plant) $)^{2} / \mathrm{P}$ accumulation in the entire plant, according to Siddiqi and Glass (1981).

The data were submitted to analysis of variance, the variables of number of leaves and number of tubers had their data transformed by the Box-Cox methodology (BOX and Cox, 1964), as they did not present a normal distribution. The averages between clones, between $\mathrm{P}$ levels and between seasons were compared using the Skott-Knott test (Scott and Knott, 1974) at 5\% probability of error, with the aid of the Sisvar 5.3 software (Ferreira, 2011).

\section{Conclusion}

Potato clones differ in the efficiency of $P$ use between the spring and fall crops in Rio Grande do Sul in an off-soil growing system with the use of sand as a substrate. The Asterix and SMINIA 793101-3 clones are more efficient in the use of $P$ when grown in the spring without restriction of $P$. The $P$ use efficiency for clone SMIC 148-A is not influenced by the growing season, as long as the availability of $P$ is not a limiting factor. The Atlantic clone shows better efficiency in the use of $P$ when grown in fall, regardless of the level of $P$ used.

\section{Acknowledgements}

The first author thanks for the financial support provided by CAPES and to the Potato Breeding Program at UFSM for granting genotypes.

\section{References}

Bandinelli MG, Bisognin DA, Gnocato FS, Mambrin RB, Sausen D, Nicoloso FT (2013) Concentração dos sais e da sacarose do meio $\mathrm{ms}$ na multiplicação in vitro e na aclimatização de batata. Hortic Bras. 31:242-247.

Beukema HB, Zaag DEVD (1990) Introduction to potato production. Wageningen Netherlands. 208.

Bisognin DA, Costa LC, Andriolo JL, Muller DR, Bandinelli MG (2008) Produtividade e qualidade de tubérculos de clones de batata. Ciên Nat. 30:43-56. 
Bisognin DA, Dellai J (2015) Shoot growth restriction in dry matter partitioning and minituber production of potato plants. Ciên Rural. 45:1917-1924.

Box GEP, Cox DR (1964) An analysis of transformations. J Royal Society. 26:211-252.

Fernandes, AM, Soratto RS, Moreno LA, Evangelista RM (2015) Qualidade de tubérculos frescos de cultivares de batata em função da nutrição fosfatada. Bragantia. 74:102-109.

Fernandes AM, Soratto RP, Evangeliosta RM, Job ALG (2016) Influência do fósforo na qualidade e produtividade de tubérculos de cultivares de batata de duplo propósito. Hortic Bras. 34:346-355.

Ferreira DF (2011) Sisvar: A computer statistical analysis system. Ciên Agrotec. 35:1039-1042.

Gnocato FS, Bisognin DA, Kielse P, Comiran M, Souza ZS (2014) Variação nos ganhos de seleção para caracteres de qualidade de tubérculos de batata na região sul do Brasil. Ciên Rural. 44:50-56.

Gondim ARO, Prado RM, Alves AU, Fonseca IM (2010) Eficiência nutricional do milho cv. BRS 1030 submetido à omissão de macronutrientes em solução nutritiva. Rev Ceres. 57:539-544.

Heldwein AB, Streck NA, Bisognin DA (2009) Batata. In: Monteiro JEBA (ed.) Agrometeorologia dos cultivos: o fator meteorológico na produção agrícola. Brasília. 91-109.

IBGE. (2017) Levantamento sistemático da produção agrícola: pesquisa mensal de previsão e acompanhamento das safras agrícolas no ano civil. Instituto brasileiro de geografia e estatística.

Lynch JP Root phenes for enhanced soil exploration and phosphorus acquisition: tools for future crops. Plant Phys. 156:1041-1049.

Mendes FF, Parentoni SN, Guimarães LJM, Guimarães PEO, Gomes PHF, Oliveira KG, Reis DP Tavares RB (2011) Seleção simultânea para eficiência de uso e resposta ao fósforo em híbridos de milho. In: Congresso brasileiro de melhoramento de plantas. Búzios.

Moura WM, Lima PC, Casali VWD, Pereira PRG, Cruz CD (2001) Eficiência nutricional para fósforo em linhagens de pimentão. Hortic Bras. 19:174-180.

Muller DR, Bisognin DA, Andriolo JL, Dellai J Copetti F (2007) Produção hidropônica de batata em diferentes concentrações de solução nutritiva e épocas de cultivo. Pesq Agropec Bras. 42:647-653.
Muller DR, Bisognin DA, Andriolo JL, Morin Junior GR, Gnocato FS (2009) Expressão dos caracteres e seleção de clones de batata nas condições de cultivo de primavera e outono. Ciên Rural. 39:1237-1334.

Murphy J, Riley JP (1962) A modified single solution method for the determination of phosphate in natural waters. Analy Chimica A. 27:31-36.

Oliveira VR, Andriolo JL, Bisognin DA, Paula AL, Trevisan AP, Antes RB (2006) Qualidade de processamento de tubérculos de batata produzidos sob diferentes disponibilidades de nitrogênio. Ciên Rural. 36:660-663.

Pereira AS (2003) Melhoramento genético; correção e adubação do solo. In: Pereira AS, Daniels J (ed..). O cultivo da batata na região sul do Brasil. Brasília. Embrapa 159.

Prezotti LC, Carmo CAS, Andrade Neto APM (1986) Nutrição mineral da batata. 44 .

Scott AJ, Knott M (1974) A cluster analysis method for grouping means in the analysis of variance. Biometrics. 30:507-512.

Siddiqi MY, Glass ADM (1981) Utilization index: a modified approach to the estimation and comparison of nutrient efficiency in plants. J Plant Nutr. 4:289-302.

Silva FL, Pinto ACBP, Alves JD, Benites FRG, Andrade CM, Rodrigues GB, Lepre AL, Bhering LL (2009) Caracterização morfofisiológica de clones precoces e tardios de batata visando à adaptação a condições tropicais. Bragantina. 68:295-302.

Silva GO, Ney VG, Pereira AS, Terres LR (2014) Relações entre caracteres de tubérculo de batata nas primeiras gerações de seleção. Rev Ceres. 61:370-376.

Souza ZS, Bisognin DA, Morin Junior GR, Gnocato FS (2011) Seleção de clones de batata para processamento industrial em condições de clima subtropical e temperado. Pesq Agropec Bras. 46:1503-1512.

Souza AT, Streck NA, Heldwein AB, Bisognin DA, Winck JEM, Rocha TSM, Zanon AJ (2014) Transpiration and leaf growth of potato clones in response to soil water deficit. Sci Agric. 71:96-104.

Tedesco MJ, Gianello C, Bissani CA, Bohnen H, Wolkweiss SJ (1995) Análise de solo, plantas e outros materiais. Porto Alegre. 174.

Vance CP, Uhde-Stone C, Allan DL (2003) Phosphorus acquisition and use: critical adaptations by plants for securing a nonrenewable resource. New Phyt. 157:423447.

Zanon AJ, Streck NA, Kräulich B, Silva MR Bisognin DA (2013) Desenvolvimento das plantas e produtividade de tubérculos de batata em clima subtropical. Rev Ciên Agronôm. 44:858-868. 